\title{
The Evaluation of Three-Dimensional Anatomy of the Superficial Temporal Artery Using the Volume Rendering Technique
}

\author{
Süperfisiyal Temporal Arterin Ü̧̧B Boyutlu Anatomisinin Hacim \\ Görüntüleme Tekniği Kullanularak Değerlendirilmesi
}

Enis KURUOGLU, Cengiz COKLUK, Abdullah Hilmi MARANGOZ, Kerameddin AYDIN

Ondokuz Mayis University, School of Medicine, Department of Neurosurgery, Samsun, Turkey

Corresponding Author: Enis KURUOGLU / E-mail: drenis@hotmail.com

\begin{abstract}
AIM: The superficial temporal artery (STA) is the one of the terminal branches of the external carotid artery. Three-dimensional anatomical structure of the STA can be evaluated by using three dimensional volume rendering technique (3D-VRT) from acquired two-dimensional contrast-enhanced computerized tomographic images.

MATERIAL and METHODS: The raw data of the Three-dimensional Computerized Tomography Angiography (3D-CTA) was transferred to computer and recorded in a software program. This software program created the three-dimensional images of STA using these transferred raw data with the volume rendering technique. These images were evaluated in terms of the location of the STA bifurcation, the distance from the some anatomical landmarks, the inner diameter of the artery, and the type of the variations.

RESULTS: The total number of patients consists of 53 ( 27 female and 26 male) patients. The mean age of the patients was estimated as $57.9 \pm 9.7$ years. It was found that the location of the STA bifurcation was over the posterior third of the zygomatic arch in $58 \%$ of the cases. In $40 \%$ of the cases the location of the bifurcation was above the zygomatic arch. The location of the bifurcation was below the zygomatic arch in the remaining part of the cases (2\%).

CONCLUSION: The STA images created using the volume rendering technique were evaluated in terms of the bifurcation point of the artery, the length of the bifurcation from some anatomical structures, the inner diameter of the artery and arterial variations. The results of this study showed that this technique might be helpful for the three-dimensional microsurgical anatomy of the STA in daily neurosurgical practice.
\end{abstract}

KEYWORDS: Superficial temporal artery, Volume rendering, Microsurgical anatomy, Three-dimensional images, Computerized tomography

\section{öz}

AMAÇ: Süperfisiyal temporal arter (STA)'in üç boyutlu anatomik yapısı, iki boyutlu kontrastlı bilgisayarlı tomografi görüntülerinden üç boyutlu hacim görüntüleme tekniği kullanılarak elde edilen görüntüler ile değerlendirilebilir.

YÖNTEM ve GEREÇLER: Ham verilerden STA'nın üç boyutlu görüntüleri oluşturuldu. Bu görüntüler, STA bifurkasyon lokalizasyonu ve bunun bazı anatomik yerlerden uzaklığı, arterin iç çapı ve varyasyonları açısından değerlendirildi.

BULGULAR: Toplam hasta sayısı 53 (27 kadın ve 26 erkek) tür. Hastaların yaş ortalaması $57.9 \pm 9.7$ yıl olarak tespit edilmiştir. STA bifurkasyon yerinin olguların \%58'inde zigomatik kemerin üçte bir arka kısmında, \%40 olguda bifurkasyon yeri zigomatik arkın üzerinde, kalan \%2 olguda zigomatik arkın altında olduğu tespit edilmiştir.

SONUÇ: Çalışmanın sonuçları bize, sözkonusu teknik ile STA'nın üç boyutlu mikrocerrahi anatomisinin ortaya konularak, günlük nörocerrahi uygulamada kullanılabileceğini göstermiş̧tir.

ANAHTAR SÖZCÜKLER: Süperfisiyal temporal arter, Hacim görüntüleme, Mikrocerrahi anatomi, Üç boyutlu görüntüler, Bilgisayarlı tomografi

\section{INTRODUCTION}

Superficial temporal artery (STA) is one of the external carotid artery branches which has the duty of feeding the scalp $(1,2)$. The facial artery, maxillary artery, occipital artery and posterior auricular artery are other arteries as they feed the scalp $(3,7)$. This artery divides as frontal and parietal branches after emerging from the external carotid artery in front of the tragus $(3,7)$. There are some variations of this artery $(1,2)$. STA has been used as an anastomosis artery for the anastomosis with distal branches of the middle cerebral artery in intracranial bypass surgery.

The volume rendering technique can be used in the three-dimensional evaluation of some anatomical structures such as STA. The volume rendering technique is a group of modalities for converting of two-dimensional images to three-dimensional images $(1,3,7)$. The two-dimensional images acquired 
by computerized tomography and magnetic resonance imaging are used to create the volume rendered images $(1,2,3)$. In this study, we used OsiriX software program for the volume rendering technique to create three-dimensional superficial temporal artery images. The results of this study and the feasibility of this technique are discussed under the light of published medical literature.

\section{MATERIAL and METHODS}

Neither additional radiological examination nor drug treatment was performed on any of the patients for this study. The patient population that was brought to our neurosurgery department because of subarachnoid hemorrhage included the cases, and we further decided to perform a 3D-CTA for cerebral aneurysm evaluation. The raw data of the 3D-CTA was transferred to a computational software database and recorded. The purpose of performing 3D-CTA was only the examination of the intracranial vascular pathology after the insult of subarachnoid hemorrhage. Some parts of these raw data were used for examination of the three dimensional anatomy of the STA by using a software program. No additional procedure was done to the patients.

The raw data obtained in DICOM format was transferred to the computer, which already had the OsiriX software program. The computer program created the three-dimensional STA images using these transferred raw data with the volume rendering technique. Three-dimensional images of the STA were evaluated in terms of the general shape of the complex, the location of the STA bifurcation, the distance from some anatomical landmarks, the inner diameter of the artery, and the type of the variations. The location of the STA bifurcation around the zygomatic arch was divided into three groups as above the superior margin of the zygomatic arch, over the zygomatic arch, and below the inferior margin of the zygomatic arch. The distance of the STA bifurcation was estimated according to three anatomical landmarks. One of them was the superior margin of the zygomatic arch if the bifurcation was located above the zygomatic arch. If the bifurcation of the STA was located below the zygomatic arch, the distance of the bifurcation was estimated from the inferior margin of the zygomatic arch. The distance of the artery from the pinna was also estimated in all cases. The inner diameter of the artery was estimated at three different points. One of them was the diameter of the parent artery at the location of the prebifurcation. Another of them was the frontal branch diameter. The last one was the parietal branch diameter. The types of the variations of the superficial temporal artery including frontal and parietal branches were also evaluated (Figure 1 and 2).

\section{RESULTS}

The total number of patients was 53 ( 27 female and 26 male). The age range of the patients was estimated as $57.9 \pm 9.7$ (Mean \pm SEM) years. None of any additional processes was performed to the patients throughout the study. The purpose of the radiological examination of the patients was only diagnosing and examining their own diseases. The radiological images of this examination were retrospectively transferred to a computer. The Three-Dimensional STA images were created with 3D-Volume Rendering Technique by using the OsiriX MD software program.

It was found that the location of the STA bifurcation was over the posterior third of the zygomatic arch in 58\% of the cases. The location of the bifurcation was above the zygomatic arch in $40 \%$ of the cases. The location of the bifurcation was below the zygomatic arch in the remaining part of the cases (2\%).

The superior margin of the zygomatic arch, mastoid tip and lateral epicanthus were selected as anatomical markers for estimation of the length of STA bifurcation. The STA bifurcation was located above the superior margin of the zygomatic arch in 21 patients (40\%). The average length of the STA bifurcation from the superior margin of the zygomatic arch was estimated as $1.41 \pm 0.77$ centimeters in cases with a superiorly located bifurcation. On the other hand, the average length of the STA bifurcation from the inferior margin of the zygomatic arch was estimated as $0.52 \pm 0.04$ centimeters in cases with an inferiorly located bifurcation. The average length of the STA bifurcation from the mastoid tip was estimated as $3.9 \pm 1.26$ centimeters. The length of the STA bifurcation from the lateral epicanthus at the same site is another parameter in the estimation of some important anatomical landmarks. The average length of the STA bifurcation from the lateral epicanthus was estimated as $6.58 \pm 0.48$ centimeters. The length of the STA from the pinna was also estimated. The average length of the STA from the pinna was $0.80 \pm 0.11$ centimeters. The internal diameter was also evaluated at three different places (parent artery, frontal branch, and parietal branch). The internal diameter of the parent artery of the STA was $0.26 \pm 0.04$ centimeters. The internal diameter of the frontal branch of STA was $0.18 \pm 0.03$ centimeters. The internal diameter of the parietal branch of STA was $0.15 \pm 0.02$ centimeters. The common variations found were frontal branch duplication, parietal branch duplication, and frontal and/or parietal branch re-bifurcations.

\section{DISCUSSION}

Three-dimensional anatomical details of the STA can be imaged using the volume rendering technique. Gross microscopic and microsurgical anatomy of the structure may be evaluated using these images. The results of the present study revealed the following details of the STA anatomy. The STA is the one of the terminal branches of the external carotid artery. Digital Subtraction Angiography is still the most sensitive diagnostic procedure in the evaluation of intracranial and extracranial vascular lesions such as aneurysms and arteriovenous malformations (7). At the same time, digital subtraction angiography is expensive, invasive, and brings an associated $1.5 \%$ to $2.0 \%$ risk of significant morbidity and mortality (9). Computerized tomographic angiography with its three-dimensional advantage is a commonly used diagnostic application for intracranial aneurysm detection. In the published literature, the diagnostic sensitivity of computerized tomographic angiography was reported 
between the range of $70 \%$ and $96 \%$ depending on the size and location of the pathology $(4,6,8,10)$.

The volume rendering technique was first developed based on research at the Mayo Clinic in the 1970s (1). The following advances in image processing hardware and integration of new data manipulation techniques were provided by the University of North Carolina and Pixar $(2,5)$. Afterwards, some important progress was achieved in parallel with hardware and software advancement in computer technology as well as image processing technology in neurological radiology. OsiriX is software for radiological image processing. Using the software can provide three-dimensional images. The three- dimensional approach provides modern rendering modes such as multiplanar reconstruction, surface rendering, volume rendering, and maximum intensity projection. In present study, we used OsiriX software for the processing of DICOM images. This software may show the basal cerebral arteries and STA together with the bone structure of the cranial base and orbital cavity.

The results of present study revealed that the location of the STA bifurcation is mainly located over the posterior third of the zygomatic arch. Average distance from the lateral epicanthus was $6.58 \pm 0.48$ centimeters. The distance from the mastoid tip was $3.9 \pm 1.26$ centimeters. The gap between the pinna and
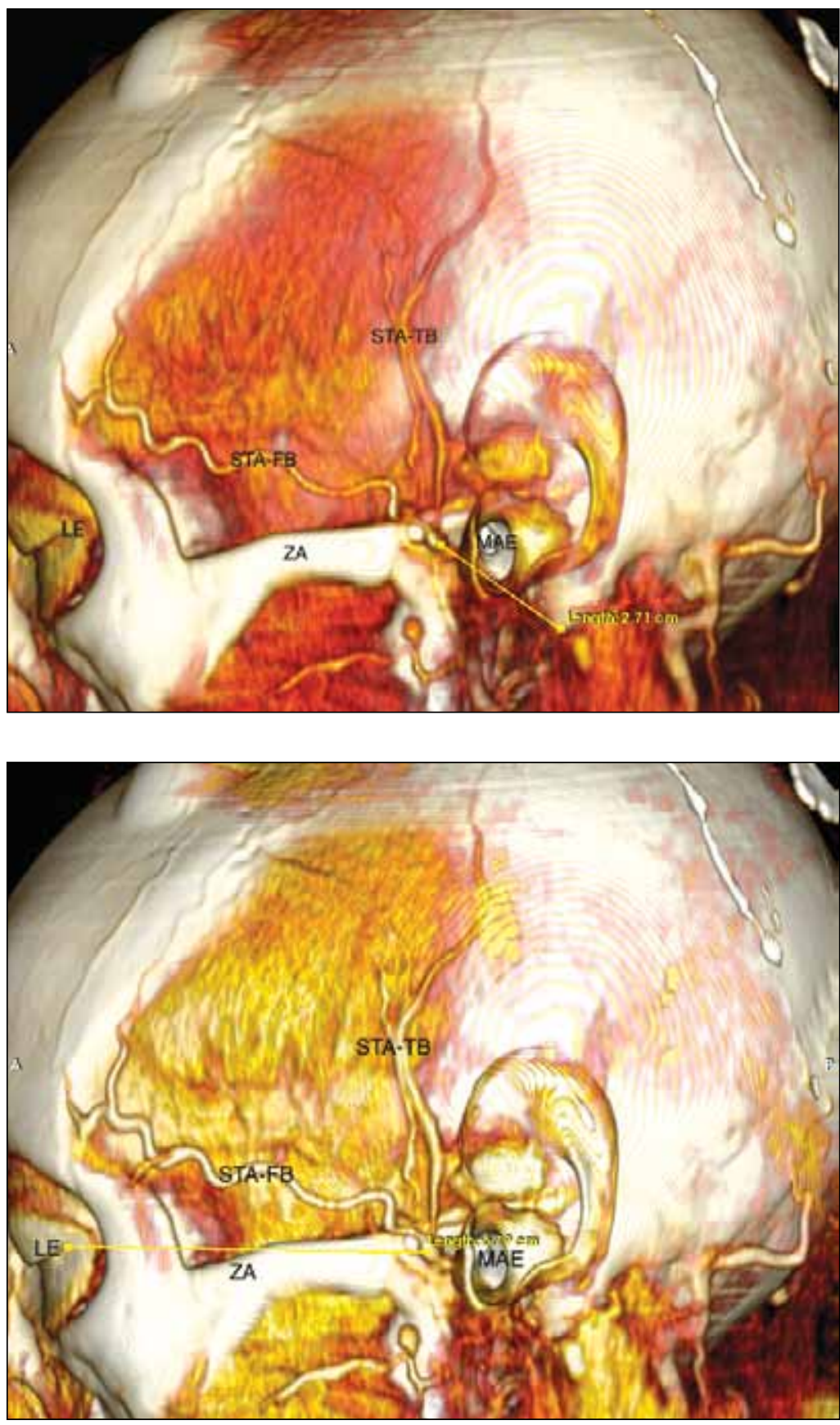

Figure 1: The three-dimensional volume rendered images of the STA in the lateral view. (MAE: meatus acusticus externus, STA-FB: superficial temporal artery-frontal branch, STA-TB: superficial temporal artery-temporal branch, ZA: zygomatic arch, LE: lateral epicanthus).
Figure 2: The three-dimensional volume rendered images of the STA with digital estimation in the lateral aspect. (MAE: meatus acusticus externus, STA-FB: superficial temporal artery-frontal branch, STA-TB: superficial temporal artery-temporal branch, ZA: zygomatic arch, LE: lateral epicanthus). 
STA was $0.80 \pm 0.11$ centimeters. This distance is important when making skin incisions around this area.

The internal diameter of the STA is also evaluated using the volume rendering technique. This technique can provide useful information about the diameter and location of the artery in cases with aneurysmal subarachnoid hemorrhage. Location of the artery can be used during skin incision planning for the preservation of the artery. Preserving the artery may keep the source preserved as a by-pass artery for blood diversion from the external carotid circulation to the internal carotid circulation.

\section{CONCLUSION}

Three-dimensional images of the head including bone and vascular structure together may give some specific dynamic information. The microsurgical anatomy of the STA could be examined using three-dimensional volume rendered images from contrast-enhanced computerized tomographic examination. Digital estimations of the segments may also be made using these images.

\section{REFERENCES}

1. Calboun PS, Kuszyk BS, Heath DG, Carley JC, Fishman EK: Three-dimensional volume rendering of spiral CT data: Theory and method. RadioGraphics 19(3): 745-763, 1999

2. Drebin RA, Carpenter L, Hanrahan P: Volume rendering. Comput Graph 22: 65-74, 1988
3. Hwang SB, Kwak HS, Han YM, Chung GH: Detection of intracranial aneurysms using three-dimensional multidetector-row CT angiography: Is bone subtraction necessary? European Journal of Radiology 79: e18-e23, 2011

4. Karamessini MT, Kagadis GC, Petsas T, et al: CT angiography with three-dimensional techniques for the early diagnosis of intracranial aneurysms: Comparison with intraarterial DSA and the surgical findings. Eur J Radiol 49: 212-223, 2004

5. Levoy M: Display of surfaces from volume data. IEEE Comput Graph Applicat 8: 29-37, 1988

6. Teksam M, McKinney A, Casey S, et al: Multi-section CT angiography for detection of cerebral aneurysms. AJNR Am J Neuroradiol 25: 1485-1492, 2004

7. Tomandi BF, Hammen T, Klotz E, Ditt H, Stemper B, Lell M: Bone-subtraction $C T$ angiography for the evaluation of intracranial aneurysms. AJNR Am J Neuroradiol 27:55-59, 2006

8. Schwartz RB, Tice HM, Hooten SM, et al: Evaluation of cerebral aneurysms with helical CT: Correlation with conventional angiography and MR angiography. Radiology, 192: 717-722, 1994

9. Waugh JR, Sachara N: Arteriographic complications in the DSA era. Radiology 182: 243-246, 1992

10. White PM, Wardlaw JM, Easton V: Can noninvasive imaging accurately depict intracranial aneurysms? A systematic review. Radiology 217: 361-370, 2000 